\title{
Survey on Socio Economic and Milking Patterns of Buffaloes Owners in Junagadh and Porbandar District of Gujarat, India
}

\author{
B.A. Pata ${ }^{1}$, M.D. Odedra ${ }^{1}$, A.R. Ahlawat ${ }^{1 *}$, H.H. Savsani ${ }^{1}$, \\ T.K. Patbandha ${ }^{1}$ and M.P. Sarma ${ }^{1}$ \\ College of Veterinary Science \& Animal Husbandry, Junagadh Agricultural University \\ Junagadh -362001, India \\ *Corresponding author
}

\section{Keywords \\ Socio economic, Milking patterns, Buffaloes owners, Gujarat \\ Article Info \\ Accepted: 08 July 2018 Available Online: 10 August 2018}

\section{A B S T R A C T}

The present investigation was carried out to study the socio-economic and milking patterns adopted by buffalo keepers in Junagadh and Porbandar districts of Gujarat State. A random sample of 300 buffalo owners were selected from three talukas of Junagadh and two talukas of Porbandar district. The study showed that a majority of buffalo owners (40\%) were literate and belonged to middle age group. In the study area, $50.34 \%$ of the buffalo owners had large land holding and had nuclear type of family. In this area $82 \%$ respondents milked buffaloes by knuckling method and most of the buffalo owners cleaned udder and teats of buffalo before milking. Majority of respondents milked their animal two times with dry hand and used open mouth bucket. Maximum (87.33\%) buffalo owners transported milk to co-operative society by themselves and practiced diagnose for mastitis in their animals.

\section{Introduction}

Livestock sector of India is one of the largest sectors in the world, comprising of 11.6 per cent of total livestock population of the world. Livestock plays an important role in Indian economy and provides livelihood to two-third of rural community. It also provides employment to about 8.8 per cent of the human population in India. India continues to be the largest producer of milk in the world. Total milk production during 2016-17 was 165.4 million tones. The per capita availability of milk was around 355 grams per day in 2016-17 (Anon., 2017).

The buffalo holds an important place in Indian rural economy. Though Buffalo is contributes almost $60 \%$ of total milk production in the country. But its contribution to international milk market is lower than many countries because our milk quality does not match export standard (Bashir et al., 2013). Scientific milking management practices like improved milking techniques, hygienic milk production and better milk let down could improve total milk production and quality of milk as well (Borghese et al., 
2007). The performance and productivity of buffaloes in the region appears to be at low level and the factors responsible need greater attention.The findings of the present study will document the present milking pattern adopted by the farmers and also provide a relevant package of that can be adopted by the farmers of this region, so that the farmers of the other region in the country are also benefited.

\section{Materials and Methods}

The present study was carried out in villages of Junagadh and Porbandar districts of Gujarat state. It was selected due to presence of large number of buffaloes, buffalo rearing farmers, familiarity of researcher with the area and local language and his ability to cover larger area within stipulated time. Two talukas from Porbandar viz Porbandar and Kutiyana and three talukas from Junagadh viz Keshod, Mangrol and Manavadar were selected and from each selected taluka 6 villages were chosen randomly. Thus samples of 300 buffalo owners were selected for the study. While selecting respondents due care was taken to ensure that they were evenly distributed in the village and was a true representative of animal management practices prevailing in the area the selected respondents were interviewed personally and information was collected with the help of predesigned questionnaire

The variables under study were selected on the basis of extensive review of literature related to the topic of research and consultation with experts. The data with regards housing and feeding management, milking management and health management were collected. classified, tabulated and analysed.

\section{Statistical analysis of the data}

Collected data were compiled, tabulated and analyzed using appropriate statistical tools and techniques like percentage, mean, frequency and standard deviation were calculated.

\section{Results and Discussion}

Personal information and socio- economic characteristics of buffalo owners

\section{Age}

Age is an important factor, which influences the behavior pattern of individual. Age influences behavior of an individual by exposing to varied situations number of times. Therefore, age of the farmer was considered as an essential aspect in this investigation.

Studies revealed that majority of (40 per cent) buffalo owners belonged to middle age group followed by young age group (32.67 per cent) and old age group (27.33 per cent). These findings are supported by Singh and Sastry (2002) and Rajput et al., (2012).

No significant difference was found between buffalo owners of Junagadh and Porbandar district (Table 1).

\section{Education}

It is considered that formal education of the respondents play an important role in adoption and performance of roles. Considering these aspects, the education of farmer was studied.

The data shown in table 2 indicated that the higher percentage (76.67 percent) of buffalo owners belonged to literate category while only 23.33 per cent of the buffalo owners were illiterate in Junagadh and Porbandar districts. These findings are supported by Rajendran and Prabaharan (2000), Arora et al., (2006) and Rathod et al., (2011) in their 
respective study areas.

Literacy per cent of buffalo owners of Junagadh district was significantly higher than buffalo owners of Porbandar district (81.11\% vs. $70 \%, \mathrm{P} \leq 0.05)$.

\section{Land holding}

Size of land holding refers to the number of acres of land owned and operated by the family of the respondent. It largely determines both economic and social status of a family in the rural areas (Table 3 ).

Majority of buffalo owners were large land holders followed by small (29.00 per cent), marginal (17.33 per cent) and landless (3.33 per cent). Large land holders were significantly higher than other groups in both districts. In this study area buffalo owner's main occupation is farming. The land holding after independence was higher in the study area. These results are contrary to the findings of Gautam et al., (2007) and Nagrale (2016).

There was significant difference between Junagadh and Porbandar district for large land holding (45.00\% vs. 58.34\%, $\mathrm{P} \leq 0.05)$.

\section{Family size}

The size of family refers the total number of individuals living together under common roof, having blood ties with each other and directly dependent on the head of the family.

Majority of respondents belonged to big size (55.67 per cent) family followed by 44.33 per cent belonged to small size of family. These findings are in accordance to Raval and Chandawat (2011), Upadhyayand Desai (2011) but contrary to the study of Jadavet al., (2014) (Table 4).

\section{Family type}

It refers to two types, nuclear and joint families that have been included in the study. The nuclear family consists of father/mother and his/her wife/husband as one conjugal and their children as one unit. The joint family is referred to that group of persons in which all members live together under one roof, cook and eat together and the earnings from all sources are pooled together and managed by one family head and also consists of two or more conjugal pairs (Table 5).

Majority of respondents (54 per cent) were from nuclear family followed by 46 percent from joint family. These findings are supported by Halakatti et al., (2007), Mande and Thombre (2009) and Saha et al., (2010).

\section{Caste}

Many farming are caste based occupations if not directly then indirectly and also certain caste of people in Gujarat especially in Junagadh and Porbandar districts have more inclination to dairy farming (Table 6).

Majority of respondents (79.34 per cent) were from $\mathrm{OBC}$ followed by 18 per cent from scheduled tribes, 1.33 per cent from general and scheduled caste group. These findings are contrary to Gautam et al., (2007) and Gangasagare and Karanjkar (2009). There was significant difference between Junagadh and Porbandar districts for OBC $(75.56 \%$ vs. $85 \%, \mathrm{P} \leq 0.05)$ and $\mathrm{ST}(22.22 \%$ vs. $11.67 \%$, $\mathrm{P} \leq 0.05$ ) categories people.

\section{Mass media exposure}

Buffalo owners keep themselves aware \& collect information through mass media like news paper, farm magazine, agriculture literature, radio/t.v. and internet (Table 7).

Majority of buffalo owners used radio/t.v. (83 percent) followed by internet (7.67 per cent), news paper (4.33 per cent), agriculture 
literature (2.67 percent) and Farm magazine (2.33 per cent).These results are in accordance to Lal et al., (2012) and Rangamma et al., (2017). No significant difference was found between two districts.

\section{Milking management practices}

Production of clean and safe milk is of utmost importance both from producer as well as consumer's point of view.

Table.1 Distribution of the buffalo owners according to their age $(n=300)$

\begin{tabular}{|c|l|c|c|c|c|}
\hline Sr.No. & \multicolumn{1}{|c|}{ Category } & Junagadh & Porbandar & Overall & $\begin{array}{c}\text { Chi-square } \\
\text { Value }\end{array}$ \\
\hline $\mathbf{1}$ & $\begin{array}{l}\text { Young age } \\
\text { ( } \leq 35 \text { years })\end{array}$ & $33.33(60)$ & $31.67(38)$ & $32.67(98)$ & 0.091 \\
\hline $\mathbf{2}$ & $\begin{array}{l}\text { Middle age } \\
\text { (36-50 years) }\end{array}$ & $37.22(67)$ & $44.16(53)$ & $40.00(120)$ & 1.447 \\
\hline $\mathbf{3}$ & $\begin{array}{l}\text { Older age } \\
\text { (> 50 years) }\end{array}$ & $29.45(53)$ & $24.17(29)$ & $27.33(82)$ & 1.010 \\
\hline & Total & $100(180)$ & $100(120)$ & $100 \quad(300)$ & \\
\hline
\end{tabular}

Percentages are mentioned without bracket (Frequencies are mentioned in bracket).

Table.2 Distribution of the buffalo owners according to their education $(n=300)$

\begin{tabular}{|c|c|c|c|c|c|}
\hline $\begin{array}{l}\text { Sr. } \\
\text { No. }\end{array}$ & Category & Junagadh & Porbandar & Overall & $\begin{array}{l}\text { Chi square } \\
\text { value }\end{array}$ \\
\hline 1 & Illiterate & $18.89(34)$ & 30.00 & 23.33 & \multirow{3}{*}{$4.969 *$} \\
\hline 2 & Literate & $81.11(146)$ & $70.00(84)$ & $76.67(230)$ & \\
\hline & Total & $100(180)$ & $100(120)$ & $100(300)$ & \\
\hline
\end{tabular}

Table.3 Distribution of the buffalo owners according to their land holding $(n=300)$

\begin{tabular}{|c|c|c|c|c|c|}
\hline $\begin{array}{l}\text { Sr. } \\
\text { No. }\end{array}$ & Category & Junagadh & Porbandar & Overall & $\begin{array}{l}\text { Chi-square } \\
\text { value }\end{array}$ \\
\hline 1 & Landless & $3.89 \quad(7)$ & $2.5(3)$ & $3.33(10)$ & 0.431 \\
\hline 2 & $\begin{array}{l}\text { Marginal (up to } 2.5 \\
\text { acres) }\end{array}$ & $18.33 \quad(33)$ & $15.83(19)$ & $17.33(52)$ & 0.314 \\
\hline 3 & Small (2.5 to 5 acres) & $32.78 \quad(59)$ & $23.33(28)$ & $29.00(87)$ & 3.119 \\
\hline 4 & Large (above 5 acres) & $45.00(81)$ & $58.34(70)$ & $50.34(151)$ & \multirow[t]{2}{*}{$5.120 *$} \\
\hline & Total & $100(180)$ & $100(120)$ & $100(300)$ & \\
\hline
\end{tabular}

$* \mathrm{P} \leq 0.05$,Percentagesare mentioned without bracket (Frequencies are mentioned in bracket) 
Table.4 Distribution of the buffalo owners according to their family size $(n=300)$

\begin{tabular}{|c|c|c|c|c|c|}
\hline Sr.No. & Category & Junagadh & Porbandar & Overall & $\begin{array}{l}\text { Chi } \\
\text { square }\end{array}$ \\
\hline 1 & $\begin{array}{l}\text { Small size (up to } 4 \\
\text { members) }\end{array}$ & $36.11(65)$ & $56.67(68)$ & $44.33(133)$ & \multirow[t]{3}{*}{$12.327 * *$} \\
\hline 2 & $\begin{array}{c}\text { Big size (above } 4 \\
\text { members) }\end{array}$ & $63.89(115)$ & $43.33(52)$ & $55.67(167)$ & \\
\hline & Total & $100(180)$ & $100(120)$ & $100(300)$ & \\
\hline
\end{tabular}

Table.5 Distribution of the buffalo owners according to their family type ( $\mathrm{n}=300$ )

\begin{tabular}{|c|c|c|c|c|c|}
\hline Sr.No. & Category & Junagadh & Porbandar & Overall & $\begin{array}{c}\text { Chi-square } \\
\text { value }\end{array}$ \\
\hline 1 & Nuclear type & $42.22(76)$ & 71.66(86) & $54.00(162)$ & \multirow[t]{3}{*}{$5.981 *$} \\
\hline 2 & Joint type & 57.78(104) & 28.33(34) & $46.00(138)$ & \\
\hline & Total & $100(180)$ & $100(120)$ & $100(300)$ & \\
\hline
\end{tabular}

Table.6 Distribution of the buffalo owners according to their caste $(n=300)$

\begin{tabular}{|c|l|l|c|c|c|}
\hline Sr.No. & Category & Junagadh & Porbandar & Overall & $\begin{array}{c}\text { Chi square } \\
\text { value }\end{array}$ \\
\hline $\mathbf{1}$ & General & $1.11(2)$ & $1.67(2)$ & $1.33(4)$ & 0.169 \\
\hline $\mathbf{2}$ & OBC & $75.56(136)$ & $85.00(102)$ & $79.34(238)$ & $\mathbf{3 . 9 1 7}$ \\
\hline $\mathbf{3}$ & SC & $1.11(2)$ & $1.67(2)$ & $1.33(4)$ & 0.169 \\
\hline $\mathbf{4}$ & ST & $22.22(40)$ & $11.67(14)$ & $18.00(54)$ & $\mathbf{5 . 4 3 5}^{*}$ \\
\hline Total & & $100(180)$ & $100(120)$ & $100(300)$ & \\
\hline
\end{tabular}

* $\mathrm{P} \leq 0.05$, Percentages are mentioned without bracket (Frequencies are mentioned in bracket)

Table.7 Distribution of the buffalo owners according to usage of mass media ( $\mathrm{n}=300)$

\begin{tabular}{|c|c|c|c|c|c|}
\hline Sr.No. & Category & Junagadh & Porbandar & Overall & $\begin{array}{c}\text { Chi square } \\
\text { value }\end{array}$ \\
\hline $\mathbf{1}$ & News paper & $2.78(5)$ & $6.67(8)$ & $4.33(13)$ & 2.627 \\
\hline $\mathbf{2}$ & Farm magazine & $1.67(3)$ & $3.33(4)$ & $2.33(7)$ & 0.827 \\
\hline $\mathbf{3}$ & $\begin{array}{c}\text { Agriculture } \\
\text { literature }\end{array}$ & $2.78(5)$ & $2.5(3)$ & $2.67(8)$ & 0.021 \\
\hline $\mathbf{4}$ & Radio/ T.V. & $84.44(152)$ & $80.83(97)$ & $83.00(249)$ & 0.665 \\
\hline $\mathbf{5}$ & Internet & $8.33(15)$ & $6.67(8)$ & $7.67(23)$ & 0.283 \\
\hline & Total & $100(180)$ & $100(120)$ & $100(300)$ & \\
\hline
\end{tabular}

Percentages are mentioned without bracket (Frequency are mentioned in bracket) 
Table.8 Distribution of buffalo owners according to milking management practices

\begin{tabular}{|c|c|c|c|c|c|}
\hline Sr. no. & Particulars & Junagadh & Porbandar & Overall & Chi square value \\
\hline \multirow[t]{4}{*}{1} & \multicolumn{5}{|l|}{ Method of milking } \\
\hline & Full hand & $16.67(30)$ & $13.33(16)$ & $15.33(46)$ & 0.616 \\
\hline & Stripping & $2.22(04)$ & $3.33(4)$ & $2.67(8)$ & 0.342 \\
\hline & Knuckling & $81.11(146)$ & $83.34(100)$ & $82.00(246)$ & 0.241 \\
\hline \multirow[t]{3}{*}{2} & \multicolumn{5}{|l|}{ Milking habit } \\
\hline & Dry hand & $72.22(130)$ & $66.67(80)$ & $70.00(210)$ & \multirow{2}{*}{1.058} \\
\hline & Wet hand & $27.78(50)$ & $33.33(40)$ & $30.00(90)$ & \\
\hline \multirow[t]{3}{*}{3} & \multicolumn{5}{|l|}{ Stripping at the end of milking } \\
\hline & Yes & $96.67(174)$ & $93.33(112)$ & 95.33(286) & \multirow[t]{2}{*}{1.798} \\
\hline & No & $3.33(06)$ & $6.67(8)$ & $4.67(14)$ & \\
\hline \multirow[t]{3}{*}{4} & \multicolumn{5}{|l|}{ Frequency of milking } \\
\hline & Two times & $97.78(176)$ & $91.67(110)$ & 95.33(286) & \multirow{2}{*}{ 6.044* } \\
\hline & Three times & $2.22(4)$ & $8.33(10)$ & $4.67(14)$ & \\
\hline \multirow[t]{3}{*}{5} & \multicolumn{5}{|l|}{ Clean udder and teats before milking } \\
\hline & Yes & $95.56(172)$ & 94.17(113) & $95.00(285)$ & \multirow[t]{2}{*}{0.292} \\
\hline & No & $4.44(8)$ & $5.83(7)$ & $5.00(15)$ & \\
\hline \multirow[t]{3}{*}{6} & \multicolumn{5}{|l|}{ Wash hand before milking } \\
\hline & Yes & $97.78(176)$ & 95.83(115) & 97.00(291) & \multirow[t]{2}{*}{0.935} \\
\hline & No & $2.22(4)$ & $4.17(5)$ & $3.00(9)$ & \\
\hline \multirow[t]{3}{*}{7} & \multicolumn{5}{|l|}{ Type of milking pail } \\
\hline & Scientific milking pail & $38.33(69)$ & $28.33(34)$ & $34.33(103)$ & \multirow{2}{*}{3.194} \\
\hline & Open mouth bucket & $61.67(111)$ & $71.67(86)$ & $65.67(197)$ & \\
\hline \multirow[t]{3}{*}{8} & \multicolumn{5}{|l|}{ Teat dipping followed } \\
\hline & Yes & $45.55(82)$ & $43.33(52)$ & $44.67(134)$ & \multirow{2}{*}{0.144} \\
\hline & No & $54.44(98)$ & $56.67(68)$ & $55.33(166)$ & \\
\hline \multirow[t]{3}{*}{9} & Place of milking & & & & \\
\hline & Milking at the same place & $82.22(148)$ & $77.5(93)$ & $80.33(241)$ & 1.016 \\
\hline & Milking at separate and dry place & $17.78(32)$ & $22.5(27)$ & 19.67(59) & \\
\hline 10 & If the buffalo do not let down milk after th & leath of calf & & & \\
\hline & Offer concentrate feed and teat manipulation & $8.89(16)$ & $12.5(15)$ & $10.33(31)$ & 1.013 \\
\hline & Oxtyocin injection & $60.55(109)$ & 79.17(95) & $68(204)$ & 10.847 \\
\hline & Dummy calf & $0(0)$ & $0(0)$ & $0(0)$ & \\
\hline & None & $30.56(55)$ & $8.33(10)$ & $21.67(65)$ & 20.949 \\
\hline 11 & Cleaning of milking utensils & & & & \\
\hline & Hot water & $51.67(93)$ & 75.83(91) & $61.33(184)$ & $17.731 * *$ \\
\hline & Tap water & $48.33(87)$ & 24.17(29) & $38.67(116)$ & \\
\hline 12 & Disposal of Milk & & & & \\
\hline & Co-operative society & $83.89(151)$ & $92.5(111)$ & $87.33(262)$ & 4.826 \\
\hline & Vendors & $1.11(2)$ & $1.67(2)$ & $1.33(4)$ & 0.169 \\
\hline & Middle man & $0(0)$ & $0(0)$ & $0(0)$ & 0 \\
\hline & Home use & $15(27)$ & $5.83(7)$ & $11.33(34)$ & 6.021 \\
\hline 13 & Test for mastitis diagnosis & & & & \\
\hline & Yes & $61.11(110)$ & $58.33(70)$ & $60.00(180)$ & 0.231 \\
\hline & No & $38.89(70)$ & $41.67(50)$ & $40.00(120)$ & \\
\hline
\end{tabular}

${ }^{*} \mathrm{P} \leq 0.05,{ }^{* *} \mathrm{P} \leq 0.01 \quad$ Percentages are mentioned without bracket (Frequencies are mentioned in bracket) 
Majority of respondents (82.00 per cent) milked buffaloes by knuckling method followed by 15.33 per cent respondents milked by full hand followed by 2.67 per cent respondents milked by stripping method. These findings are contrary with Bashir et al., (2013) who studied that majority (73.33 per cent) of dairy farmers were following full hand method, 18.33 per cent and 8.33 per cent were following knuckling and machine milking respectively as method of milking and the findings are also supported by Sreedhar et al., (2017) who indicated that 78.34per cent of farmers followed knuckling method in the study area. Majority of the farmers did not practice complete milking. There was no significant difference found between the Junagadh and Porbandar district related to milking method of buffaloes.

Data of 8.2 revealed that majority of respondents 70 per cent respondents milked their animals with dry hand followed by 30 per cent respondents who milked with wet hand. These findings are contrary with findings of Tewari et al., (2018), who concluded that wet hand milking was found to be a common practice adopted by 85.50 per cent farmers. There was no significant difference found between the Junagadh and Porbandar district related to milking habit of respondents.

Data presented in table 8 revealed that 95.33 per cent respondents practiced stripping end of milking followed by 4.67 per cent respondents did not practice stripping end of milking. These results are supported by Swaroop and Prasad (2009) who observed that 73 per cent of the respondents followed stripping at the end of milking. There was no significant difference found between the Junagadh and Porbandar district related for stripping at the end of milking.

Data presented in table 8 indicated that 95.33 per cent respondents milked twice while only
4.67 per cent respondents milked three times. These results are similar with Bashir et al., (2013), who studied that all the dairy farmers practiced two times milking a day. Tewari et al., (2018) concluded that majority of the farmers $(90.50$ per cent) practiced milking twice in their animals. In Junagadh district more no. of respondents two time practiced to milk to their buffaloes compare to Porbandar district $(97.78 \%$ vs $91.67 \%, \mathrm{P} \leq 0.05)$.

Data of table 8 indicated that 95 per cent respondents cleaned udder and teats before milking followed by 5 per cent buffalo owners who did not clean udder, teats before milking. These results are supported by Sreedhar et al., (2017), who studied that all the milkers cleaned the udder and teats and Meena et al., (2008) found that about 80.33 per cent of milk producers washed the udder with clean water. There was no significant difference found between the Junagadh and Porbandar district related for practiced to clean udder and teats before milking. Data of table 8 indicated that 97.00 per cent respondents washed their hands before milking followed by 3 per cent respondents who did not wash hands before milking. These results are supported by Bainwad et al., (2007) and Sreedhar et al., (2017), who reported that all the milkers washed their hands before milking. There was no significant difference found between the Junagadh and Porbandar district related for washed hand before milking.

Data of table 8 indicated that. 65.67 per cent respondents used open mouth bucket as milking pail followed by 34.33 per cent respondents who used scientific milking pail. These results are supported by Sreedhar et al., (2017), who studied that open mouth buckets were used by 98.33 per cent of the farmers for milking the animals. There was no significant difference found between the Junagadh and Porbandar district related to type of milking pail. 
Data of table 8 indicated that. 55.33 per cent respondents did not practice to dip teat of buffalo in antiseptic solution followed by 44.67 per cent respondents practiced to dip teat of buffalo in antiseptic solution. These results are supported to Sreedhar et al., (2017), who studied that majority of the farmers did not practice complete milking, teat dipping in antiseptic lotion after milking and mastitis prevention measures. There was no significant difference found between the Junagadh and Porbandar district.

Data of table 8 revealed that. 80.33 per cent respondents practiced to milking at same place while 19.67 per cent buffalo owners practiced milking their buffaloes at separate place. These findings are supported by Bashir et al., (2013) who studied that only 11.67 per cent of the dairy farmers milking their animals in separate and dry places. There was no significant difference found between the Junagadh and Porbandar district related to place of milking.

Data of table 8 revealed that 68 per cent buffalo owners injected oxytocin if the buffalo did not let down milk followed by 21.67 per cent who did not any practice followed by 10.33 per cent respondents offered concentrate to their buffalo. No one kept dummy calf if the buffalo did not let down milk. There was no significant difference found between the Junagadh and Porbandar district related for practiced follow if the buffalo did not let down milk.

Data of table 8 revealed that. 61.33 per cent buffalo owners cleaned milking utensil with hot water followed by 38.67 per cent buffalo owners cleaned milking utensil tap water. Kushwahaet al., (2007) surveyed that majority of the farmers 92 per cent of the respondents adopted the practice of cleaning of milking utensils with hot water. In
Junagadh district more no. of respondents cleaned milking utensil with tap water compare to Porbandar district $(48.33 \%$ vs. $24.17 \%, \mathrm{P} \leq 0.01$ ), however In Porbandar district more no. of respondents cleaned milking utensil with hot water compare to Junagadh district (75.83 vs. 51.67\%).

Data of table 8 revealed that 87.33 per cent buffalo owners transported milk in cooperative society followed by 11.33 per cent buffalo owners kept milk for home use followed by 1.33 per cent buffalo owners transported to vendors. No one transported milk to middle man. These results are supported by Sreedhar et al., (2017), who studied that only 28.33 per cent of the farmers have consumed milk for family consumption and the rest sold to consumers rather than corporative societies and government/ non government organizations in the Rayalaseema Region of Andhra Pradesh. There was no significant differences found between the Junagadh and Porbandar district related for did practice to disposal/ transport milk.

Data of 8.13 indicated that 60 per cent buffalo owners practiced test for mastitis diagnosis while 40 per cent buffalo owners did not practice test for mastitis diagnosis. Tewari et $a l$. , (2018) indicated that 60.00 per cent farmers checked their animals for mastitis only when it was required in the Tarai region of Uttarakhand state. There was no significant difference found between the Junagadh and Porbandar district for test of mastitis diagnosis.

\section{References}

Anonymous, (2017). District; a profile, retrieved from: Gujarat.nic.in/pg district Profile.html, Downloaded from: en.wikipedia.org/wiki.

Arora, A. S., Kumar, A., Bardhan, D. and Dabas, Y.P. S. (2006). Socio- 
economic and communicational variables associated with level of knowledge and degree of adoption of improved dairy husbandry practices in U.S. Nagar district of Uttaranchal. Indian Journal of Dairy Science, 59(5): 337-343.

Bainwad, D. V., Deshmukh, B. R., Thombre, B. M. and Chauhan, D. S. (2007). Feeding and management practices adopted by buffalo farmers under watershed area. Indian Journal of Animal Research, 41(1): 68-70.

Bashir, B.P. and Kumar, V.G. (2013). Milking management practices followed in selected areas of the Kottayam district of Kerala state. Journal of Life Science, 5(1): 53-55.

Borghese, A., Milking management of dairy buffalo, Italian Journal of Animal Science. 6 (Suppl. 2): 39-50 (2007).

Gangasagare, P. T. and Karanjkar, L. M. (2009). Status of milk Production and economic profile of dairy farmers in the Marathwada region of Maharashtra. Veterinary World, 2(8): 317-320.

Gautam, U. S., Chand, R. and Singh, D. K.(2007). Socio-personal correlation of Decision- making and adoption of dairy practices. Indian Research Journal Extension Education,7(2-3) : 10-11.

Halakatti, S. V., Sajjan, C. M., Gowda, D. S. M. and Kamaraddi, V. (2007). Empowerment of women through dairy training. Karnataka Journal of Agriculture Science, 20(1): 89-92.

Jadav, S. J., Rani, D. V., Pansuriya, D. V., Chaudhary, J. H., Chauhan, V.D. and Pandya S. S. (2014). Feeding practices of dairy animals in periurban areas of Surat district (Gujarat). International Journal Advanced Multidisciplinary Research, 1(3): 1-5.
Kushwaha, B. P., Kundu, S. S., Kumar, A., Maity, S. B. and Singh, S. (2007). Status of Bhadawari breed of buffalo in its breeding tract and its conservation. Indian Journal of Animal Science, 77(12): 1293-1297.

Mande, J. V. and Thombre, B. M. (2009). Adoption of cattle rearing practices by dairy cattle owners in Latur district. Journal of Dairying, Foods \& Home Science, 28(3\&4): 176-180.

Meena, H. R., Ram, H., Sahoo, A. and Rasool, T. J. (2008). Livestock husbandry scenario at high altitude Kumaon Himalaya. Indian Journal of Animal Science, 78(8): 882-886.

Nagrale, S. G. (2016). Studies on feeding and management practices adopted in livestock fodder camps during drought in Kaijtahsil of Beed district. M.Sc. (Agri.) thesis submitted to VNMKV, Parbhani.

Rajendran, K. and Prabaharan, R. (2000). Socio-economic status of milk producers in a backward district (Dharmapuri) of Tamil Nadu. Indian Veterinary Journal, 77(2): 157-158.

Rajput, B. P. S.,Sahu, N.C., Kant, K. and Kumar, R. (2012). Perceived Training Needs of Dairy Farmers Regarding Improved Dairy Farming Practices and its Relation with their Socioeconomic Traits in Bundelkhand Region. Indian Journal of Dairy Science, 65(4): 342-347.

Rangamma, B., Rao, J., Prasad, R.M. and Rao, R. (2017). A study on social profile of buffalo milk producers in Krishna district of Andhra Pradesh. International Journal of Science, Environment, 6(4): 2291-2297.

Rathod, P. K., Landge, S., Nikam, T. R. and Vajreshwari. (2011). Socio-personal profile and constraints of dairy farmers. Karnataka Journal of Agriculture Science, 24(4): 619-621. 
Saha, D., Akand, A.H. and Hai, A. (2010). Livestock farmers' knowledge about rearing practices in Ganderbal district of Jammu \& Kashmir. Indian Research Journal of Extension Education,10(2): 15-19.

Singh, B. P. and Sastry, K. V. H. (2002). Study of tribal dairy farmers. Journal of Dairying Foods \& Home Science, 21(1): 40-43.

Sreedhar, S., Reddy, A. N., Ramesh Babu, P., Sudhakar, B.V., Kamalakar, G. and Tejaswi, V. (2017). Milking management practices and marketing of milk in Rayalaseema region of Andhra Pradesh. International Journal of Pure And Applied Bio Sciences, 5(6): 524-530.
Swaroop, D. and Prasad, J. (2009). Housing systems of dairy cattle and buffaloes in rural area of trans-Yamuna Allahabad district. National symposium on 'organic livestock farming- global issues, trends and challenges' held at Kolkata, Indian society of animal production and management during $26^{\text {th }}-28^{\text {th }}$ February, pp. 178.

Tewari, H., Kumar, S., Singh, D. V., Rath, R. and Tyagi, K. (2018).Studies on existing milking and health care practices adopted by dairy farmers in Tarai region of Uttarakhand, India. Indian Journal of Animal Research, 52 (3): 454-458.

\section{How to cite this article:}

Pata, B.A., M.D. Odedra, A.R. Ahlawat, H.H. Savsani and T.K. Patbandha and Sarma, M.P. 2018. Survey on Socio Economic and Milking Patterns of Buffaloes Owners in Junagadh and Porbandar District of Gujarat. Int.J.Curr.Microbiol.App.Sci. 7(08): 1203-1212. doi: https://doi.org/10.20546/ijcmas.2018.708.135 